\title{
THE CREDIT SUPPLY CHANNEL OF MONETARY POLICY TRANSMISSION MECHANISM: AN EMPIRICAL INVESTIGATION OF ISLAMIC BANKS IN PAKISTAN VERSUS MALAYSIA
}

\author{
Syed Muhammad Abdur Rehman Shah ${ }^{1}$ and Abdul Rashid ${ }^{2}$ \\ ${ }^{1}$ Assistant Professor, University of Engineering and Technology Taxila, Pakistan, \\ a.rehman@uettaxila.edu.pk \\ ${ }^{2}$ Economics (IIIE), International Islamic University (IIU), Islamabad, Pakistan, \\ abdulrashid@iiu.edu.pk
}

\begin{abstract}
The transmission mechanism of monetary policy is explained through the relationships between a change in money supply and the level of real income. Monetary policy transmits to the real sector through several different channels. Such channels include the interest rate channel, the exchange rate channel, the asset-pricing channel, the credit supply channel, and the bank balance sheet channel. This paper empirically investigates the credit supply channel of monetary policy and explores the differential impact of monetary policy on credit supply of Islamic banks in Pakistan versus Malaysia. The robust two-step System-Generalize Method of Moments (GMM) estimator is applied on an unbalanced panel dataset over the period 2005-2016. While estimating the effects of three alternative measures of monetary policy on banks' credit supply, several bankspecific variables are included in the specification as control variables. We provide strong evidence on the existence of credit supply channel in the baseline models for both countries and differential impact of monetary policy through Islamic banks in Pakistan versus Malaysia in the extended models. Our findings suggest that there is a vital need to consider the nature of Islamic banks while devising the instruments of an effective monetary policy in countries with dual banking system like Pakistan, Malaysia, Indonesia, Bahrain, Saudi Arabia, Qatar and others.
\end{abstract}

Keywords: Credit Supply Channel, Loan Supply, Monetary Policy, Bank Lending Channel, Islamic Banks, Transmission Mechanism.

JEL Classifications: G15; E52; E42; G21.

\author{
Article history: \\ Received : : September 26, 2018 \\ Revised : February 20, 2019 \\ Accepted : : February 26, 2019 \\ Available online : March 15, 2019
}

https://doi.org/10.21098/jimf.v5i1.1046 


\section{INTRODUCTION}

Monetary policy intends to enhance economic growth and financial stability by controlling the money supply and credit in the economy. According to the traditional theories of monetary policy, the money supply is the main instrument, and any change in the level of money supply in the economy will result changes in the market interest rate and overall spending (Friedman and Schwartz, 1963; King and Plosser, 1984; Sim, 1992). On the other hand, according to the new theories of monetary policy, banks play an important role in monetary policy transmission mechanism. Nevertheless, the extent at which banks accelerate monetary policy transmission mechanism mainly depends on two aspects: (1) how much banks rely on their deposits, and (2) how much borrowers are bank dependent.

In principle, the effect of monetary policy on the economy can be channelized through various channels. These channels commonly include the interest rate channel, the credit supply channel, the exchange rate channel, and the assetpricing channel. However, the credit supply channel of banks came to the forefront after the 2007-2008 global financial crisis that adversely affected the stability of the banking sector. This channel emphasizes on the role of banking sector in the transformation of monetary policy. The credit channel of monetary policy transmission mainly works through the bank lending channel and the balance sheet channel (Bernanke and Gertler, 1995). Due to the failure of conventional interest rate channel, Mishkin (1996) also explains the credit channel of monetary policy transformation by introducing the role of asymmetric information in financial markets.

Upon reviewing the empirical literature, we find that several known scholars have confirmed the monetary transmission mechanism through these channels for different economies. Examples of these researchers, among several others, include Bernanke (1993), Kashyap and Stein (1994), Bernanke and Gertler (1995), and Cecchetti (1995). In the bank-centric view of monetary transmission, it is assumed that money, bonds, and bank loans are three important types of assets. In this perspective, the response of banks to monetary policy actions would be the lending response of banks to monetary policy shocks.

There are several empirical studies on the examination of role of conventional banks in the monetary transmission process. One of the common findings emerging from these studies is that banks play an important role in formulating the effects of monetary policy on the economy. However, in the last two decades, in several Muslim as well as in non-Muslim countries, Islamic banking has attracted the attention of scholars, policymakers, customers, and investors. In particular, Islamic financial system in general and Islamic baking in specific became popular during and after the 2007-2008 global financial crisis. In these days, several countries across the globe are running both Islamic and conventional banking parallel. Therefore, in the countries having dual banking system, Islamic banks, along with conventional banks, have an important role to play in transforming the effects of any policy related to banking sector in the economy. Specifically, Islamic banks are expected to play a significant role yet quite different than that of the conventional counterpart in the monetary policy transmission mechanism. On empirical grounds, however, we know less about the relative role of Islamic banks in channeling the monetary policy effects to the real economic activities. 
Nonetheless, it is worthwhile to know the role of Islamic banks for an effective transmission of monetary policy in the economy. Therefore, this paper fills the gap through exploring the relative role of Islamic banks in the monetary policy transmission of Pakistan and Malaysia empirically. For this purpose, the paper investigates the banks' credit channels by focusing on the bank lending channel and the balance sheet channel in line with Bernanke and Gertler (1995).

Islamic banks are different in nature and composition of assets and liabilities as compared to their conventional counterparts. Therefore, on basis of unique contractual and motivational features of Islamic financial institutions (IFIs), Hardianto (2004), Kaleem and Isa (2006), Sukmana and Kassim (2010), and Zaheer, Ongena and Wijnbergen (2013) using aggregate data on Islamic banking have examined the responses of Islamic financing to monetary policy. However, one should note that the focus of these studies was on consolidated macroeconomic data of Islamic banks rather than the bank-level data. Most of these studies have documented that there is a potential gap to explore the responses of microeconomic (bank-level) data of Islamic banks to monetary policy shocks. Empirical evidence based on bank-level data will definitely help to achieve the macroeconomic objectives of monetary policy. Indeed, if both Islamic and conventional banks are the part of financial system, then any instrument of monetary policy should have to affect the economy by affecting both types of banking. Thus, it is worth exploring whether Islamic banks hinder or intensify the monetary policy transmission mechanism. Yet, until now we know less about the relative role of Islamic banking in monetary policy transmission mechanism. Therefore, this paper aims to explore the role of the credit channel of monetary policy by focusing on the role of Islamic banks in Pakistan and Malaysia. To do so, this study uses a sample of five fullfledged Islamic banks and six Islamic branches/divisions of conventional banks of Pakistan. As for Malaysia, we selected eleven Islamic banks for empirical analysis. Our analytical framework enables us to examine the bank-centric view of credit supply channel of monetary policy transmission mechanism through Islamic banks in Pakistan and Malaysia. Specifically, we examine whether tight monetary policy affects more Islamic banks' credit supply in as compared to the conventional counterpart in both Pakistan and Malaysia. We also examine whether Islamic banks are more effectual in the transmission of monetary policy effects to the real economy in Pakistan or Malaysia. There are several policy implications for monetary policy authorities of economies with dual banking system like Pakistan, Malaysia, Indonesia, Bahrain, Saudi Arabia, Qatar and others.

The rest of the paper is structured as follows. Section 2 reviews the empirical literature on monetary policy transmission mechanism. Section 3 describes data and presents the empirical framework. Section 4 presents the empirical findings. Finally, Section 5 presents some conclusions and policy recommendations.

\section{REVIEW OF EMPIRICAL LITERATUTE}

The bank-lending channel works mainly through the responses of credit supply to the indicators of monetary policy such as interest rates and other policy instruments. Therefore, the credit channel can also be said an enhancement mechanism of the interest rate channel of monetary policy transmission mechanism. Bernanke 
and Blinder (1988) are the first who laid down the foundation for the roles of banks in monetary policy transmission. Bernanke and Blinder (1992), Kashyap and Stein (2000), and Kishan and Opiela (2000) have confirmed the presence of lending channel in the United States. Most of the studies deal with the responses of credit supplies of banks from distinct characteristics, like banks' size, the level of liquidity and banks' capital. Bernanke, Gertler, and Gilchrist (1999) extend the New Keynesian model to account for the balance sheet channel of monetary transmission. Kashyap and Stein (1997) have documented that small-sized banks reduce their lending more than large-sized banks in response of tight monetary policy in the USA. Similarly, Kashyap and Stein (1997), Cecchetti (1999), Ehrmann and Smets (2003) and Santis and Surico (2013) have explored some descriptive evidence on credit supply channel for the EU countries. In line with the previous studies, Aysun and Hepp (2013), Wong (2000), Kashyab and Stein (1995), Bernanke and Lown (1991), Evans, Fisher, Gourio, and Kran (2015), Auclert (2017), Erdogdu (2017), Anwar and Nguyend (2018), and Jermann (2019) have documented the credit view of monetary transmission mechanism.

In Pakistan, Janjua, Rashid, and Qurrat-Ul-Ain (2014) empirically examined the presence of the bank-centric view of credit supply using annual data on banks over the period 2006-2012 for a large sample of banks. They find that there is significant negative association between monetary measures and banks' loan supply. They also show that small-sized banks are likely to be more affected than large banks during tight monetary policy. However, one should note that they do not explore the relative role of Islamic versus conventional banks in the transmission mechanism of monetary in Pakistan, which is the core theme of this study.

Islamic banking is an emerging market over the globe and this industry holds a substantial share of credit supply in countries like Pakistan with dual banking system: running both Islamic and conventional banking system. In Pakistan and Malaysia, Islamic banking is recorded at 11.6 percent and 35.4 percent, respectively, as the market share of total banking assets and Islamic deposits are recorded at 13.7 percent and 38.7 percent, respectively, of banking industry by the end of June 2017. Further, the capital structure decisions of Islamic banks operating in Pakistan are also found empirically with unique features (Shah, Rashid and Khaleequzzaman, 2017). Zaheer, Ongena and Wijnbergen (2013) using aggregate data on Islamic banking examine the response of Islamic financing to monetary policy and found that Islamic financing continues to grow even in periods of tight monetary policy irrespective of their size and the level of liquidity.

In Malaysia, Sanrego \& Rusydiana (2013) and Alaro \& Hakeem (2011) argue that an economic agent substitutes the loan-based credit by available profit-loss sharing credit in Islamic banks. As a result, this Shari'ah mechanism creates a balance between monetary and real sectors of the economy, controlling inflation as well. Similarly, Hasin and Majid (2012) differentiate Islamic banks to conventional counterpart on the basis of alternate products on both sides of balance sheet, despite of meeting the same demand of market. These products of Islamic banking are based upon a variety of underlying contracts. It is notable that Sukmana and Kassim (2010) stated that Islamic banks also play a vital role in transmission process of monetary policy through credit supply channel in Malaysia. Further, 
the policy makers should consider fundamental differences of dual banking system. Otherwise, there may appear puzzles to monetary policy (Chapra, 1985; Chaudary and Mirakhor, 1997; Farahani and Masood, 2013). Similarly, on basis of unique contractual and motivational features of Islamic financial institutions (IFIs), Hardianto (2004), Kaleem and Isa (2006), Sukmana and Kassim (2010) and Zaheer, Ongena and Wijnbergen (2013) indicated the potential gaps that requires to explore the credit supply channels through Shari'ah based financing instruments to achieve the macroeconomic objectives of monetary policy. More recently, Shah, Rashid, and Mansoori (2018), Akhatova, Zainal, and Ibrahim (2016) and Stepanchuk and Tsyrennikov (2015) evaluated comparatively the credit channel of Islamic banks and conventional banks through the lending rate, the deposit rate and the interest rate spread as monetary policy measures.

Overall, these empirical studies have examined the responses of Islamic financing to monetary policy using aggregate data of different countries with dual banking system. However, one should note that the focus of these studies was on consolidated macroeconomic data of Islamic banks rather than the bank-level data. Most of these studies have documented that there is a potential gap to explore the responses of microeconomic (bank-level) data of Islamic banks to monetary policy shocks. Yet, we know less about the relative role of Islamic banking in the monetary policy transmission mechanism. Therefore, this paper contributes to the literature on the monetary policy transmission mechanism by exploring the bankcentric view of credit supply channel for Islamic banks in Pakistan and Malaysia with respect to their responses to monetary policy tightening.

\section{DESIGN OF METHODOLOGY}

\subsection{Data and Sample Sources}

This paper uses dataset of Islamic banks along with selected macroeconomic variables and monetary policy indicators from Pakistan and Malaysia. We construct an unbalanced annual panel dataset for banking sector of both countries through various sources. There are some differences in accounting treatment of different economic activities because of the fundamental differences of the conceptual models of both Islamic and conventional banks. Data on policy variables are also collected from central banks of Pakistan and Malaysia to observe the impact of monetary policy stances on the credit supply of Islamic banks of both countries.

This study uses a sample of five full-fledged Islamic banks, six Islamic branches/ divisions of conventional banks of Pakistan. For Malaysia, we have selected eleven Islamic banks for empirical analysis. Overall, the data on bank-specific and macroeconomic variables are collected from financial statements of banks, available on their websites. In both countries, banks are selected based on the availability of the data on the required variables. We have also collected some data from the publications of State Bank of Pakistan (SBP) and Bank Nagara Malaysia (BNM), World Development Index (WDI), International Financial Statistics (IFS) of IMF, and Orbis Bank Focus (Bankscope). Some data of Islamic branches/divisions of conventional banks are taken from Thomson Reuters Datastream. 


\subsection{Model Specification}

We estimate two empirical models for Pakistan and Malaysia with several different specifications to achieve the objectives of this paper. In line with Kashyab and Stein (1994), these models explore the impact of monetary policy on credit supply of Islamic banks with some additional specifications. These models are developed to examine the responses of Islamic banks' credit supply to monetary policy indicators, along with bank specific variables and macroeconomic conditions in Eq.(1). Both models for each country would be regressed in the following Eq.(1).

$$
Y_{i t}=\beta_{i}+X_{i t} \alpha+Z_{t} \theta+\rho M_{t}+\mu_{t}+\varepsilon_{i t}
$$

$\mathrm{Y}_{\mathrm{it}} \quad=$ Islamic banks' credit supply

$\beta_{\mathrm{i}}=$ Individual-specific effect

$\mu_{t} \quad=$ Year-specific effect

$\varepsilon_{\text {it }} \quad=$ Error term

$X_{i t}=$ A group of bank-specific variables that include size, liquidity, capital, coverage ratio, credit risk, profitability, and the debt to equity ratio.

$\mathrm{Z}_{\mathrm{t}} \quad=\mathrm{A}$ group of macroeconomic variables that include Gross Domestic Product (GDP) growth and inflation

$\mathrm{M}_{\mathrm{t}}=$ A group of monetary policy indicators: the lending interest rate, the deposit interest rate, and the interest rate-spread.

We selected the bank-specific, the macroeconomic and the monetary policy variables to examine the existence credit view of monetary policy and different responses of Islamic versus conventional banks' credit supply. The rationale of selection of these specific variables is discussed in detail. First, we begin with the dependent variable that is banks' credit supply. The banks' credit supply is defined as the ratio of gross loans to total assets in case of conventional banks and as financing to total assets according to the financial statements of Islamic banks in line with Akhatova, Zainal, and Ibrahim (2016) in Malaysia and Shah, Rashid, and Mansoori (2018) in Pakistan. This study intends to investigate the effects of monetary policy indicators on the credit supply decision of banks. As credit supply of banks decreases due to an increase in policy interest rate, it employs the existence of the bank-centric view of credit supply channel (Alper, Hulagu and Keles, 2012; Sukmana and Kasim, 2010). The bank-specific independent variables are there described in Table 1. In line with Kashyab and Stein (1995), the lending interest rate, the deposit interest rate, and the interest rate-spread are used as difference between the lending interest rate and the deposit interest rate. Similarly, these three interest rates are selected as measures of monetary policy.

\subsection{Variables Construction}

We selected the dataset of Pakistan and Malaysia to investigate responses of Islamic to monetary policy actions because of the following solid reasons. First, the economies of Pakistan and Malaysia are almost banks' dependent, which increases importance of banks' credit cannel of monetary policy transmission. Second, both Pakistan and Malaysia have the economies with dual banking system: Islamic 
and conventional banks in the financial system with modern practices. Third, these both countries are using accounting system in line with modern practices of international accounting standards for their financial institutions. Moreover, Islamic banking operations are in line with modern practices of Accounting, Auditing Organization of Islamic Financial Institutions (AAOIFI) and Islamic Financial Services Board (IFSB) through central banks in Pakistan, State Bank of Pakistan (SBP) and Malaysia, Bank Negara Malaysia (BNM) with some additional Shari'ah compliance requirements to be regulated through Shari'ah governance framework. Fourth, the accounting differences of both banking strands are harmonized to make them comparable for further analysis in the same economy. Last, data of Islamic banks are easily available and managed by their central banks.

Table 1.

Description of Bank-Specific Variables

\begin{tabular}{ll}
\hline Variables & \multicolumn{1}{c}{ Description } \\
\hline Bank credit supply & Ratio of gross loans to total assets \\
Bank size & Log of total asset \\
Liquidity & Cash and cash equivalent divided by total assets \\
Capital & Capital ratio, i.e. (total shareholder equity/total assets) ${ }^{*} 100$ \\
Coverage ratio & (EBIT/Interest Expanse) ${ }^{*} 100$ \\
Credit risk & Ratio of classified loans to total loans \\
Profitability & (Profit after tax/total assets) ${ }^{*} 100$ \\
Debt to equity ratio & $\begin{array}{l}\text { Debt/Equity Ratio is a debt ratio used to measure a company's financial leverage, } \\
\text { calculated by dividing a company's total liabilities by its stockholders' equity. }\end{array}$ \\
\hline
\end{tabular}

\subsection{Estimation Technique}

We apply the robust two-step system-the Generalize Method of Moments (GMM) estimator. Such a system was proposed by Arellano and Bover (1995) and then it was fully developed by Blundell and Bond (1998). This estimator is widely used in the literature and has several advantages over other panel data estimators. Specifically, it effectively mitigates the problem of endogeneity and cross-sectional correlation by allowing the researchers to use both level and first difference instruments. The Arellano and Bond (1991) AR (2) is applied to test the existence of the second order serial correlation in the residuals. Further, the J-test of Hansen (1982) is employed to test the null hypothesis of the instruments are orthogonal to the residuals.

\section{EMPIRICAL FINDINGS}

\subsection{Findings for Pakistan}

The results for Pakistan are presented in Table 2. Panel A and Panel B present the empirical results of variables and diagnostic tests, respectively. In Panel A of Table 2, all the three monetary policy indicators: the lending interest rate, the interest rate-spread, and the deposit rate are negatively and significantly related to the credit supply of banks. The empirical evidence supports the presence of the bank- 
centric view of monetary policy and is robust to all the three alternate measures of monetary policy used in the analysis (Kashyab and Stein, 1994). Similarly, these results are in accordance with the existing literature, such as Sharpe (1995), Hasin and Majid (2012), and Janjua, Rashid, and Qurrat-Ul-Ain (2014).

Table 2.

Impact of Monetary Policy Indicators on Islamic Banks' Credit Supply in Pakistan

\begin{tabular}{|c|c|c|c|c|c|c|}
\hline \multicolumn{7}{|c|}{ Panel A: Estimation Results } \\
\hline & \multicolumn{2}{|c|}{ Model 1(a) } & \multicolumn{2}{|c|}{ Model 1(b) } & \multicolumn{2}{|c|}{ Model(c) } \\
\hline Variables & Coefficient & Std. Error & Coefficient & Std. Error & Coefficient & Std. Error \\
\hline Lagged Debt Ratio & $0.618^{* * *}$ & 0.119 & $0.739^{* * *}$ & 0.045 & $0.749^{* * *}$ & 0.060 \\
\hline Banks size & $0.049^{* * *}$ & 0.017 & $0.025^{* * *}$ & 0.011 & $0.029^{* *}$ & 0.015 \\
\hline Banks Liquidity & -0.296 & 0.343 & -0.150 & 0.142 & -0.239 & 0.111 \\
\hline Banks Capital & $0.005^{* * *}$ & 0.002 & $0.005^{* * *}$ & 0.001 & $0.005^{* * *}$ & 0.001 \\
\hline Coverage ratio & $0.007^{* *}$ & 0.003 & $0.001^{* *}$ & 0.001 & $0.000^{* * *}$ & 0.001 \\
\hline Credit risk & $-0.178^{* *}$ & 0.155 & $-0.442^{* * *}$ & 0.168 & $-0.514^{* * *}$ & 0.172 \\
\hline Banks Profitability & $0.014^{* * *}$ & 0.004 & $0.011^{* * *}$ & 0.003 & $0.024^{* * *}$ & 0.007 \\
\hline Debt to equity ratio & $0.012^{* *}$ & 0.001 & $0.002^{* * *}$ & 0.002 & $0.001^{* * *}$ & 0.001 \\
\hline Lending rate & $-0.022^{* * *}$ & 0.006 & & & & \\
\hline Interest rate spread & & & $-0.024^{* * *}$ & 0.003 & & \\
\hline Deposit rate & & & & & $-0.021^{* * *}$ & 0.003 \\
\hline GDP Growth & $12.564^{* *}$ & 7.654 & $7.123^{* * *}$ & 2.435 & $3.543^{* * *}$ & 1.654 \\
\hline Inflation & $0.069^{* * *}$ & 0.023 & $0.027^{* * *}$ & 0.009 & $0.013^{* *}$ & 0.008 \\
\hline Constants & $45.449^{* *}$ & 15.483 & $27.818^{* * *}$ & 8.875 & $15.798^{* * *}$ & 5.783 \\
\hline \multicolumn{7}{|c|}{ Panel B: Diagnostic Tests } \\
\hline Observations & \multicolumn{2}{|c|}{103} & \multicolumn{2}{|c|}{103} & \multicolumn{2}{|c|}{103} \\
\hline Banks & \multicolumn{2}{|c|}{11} & \multicolumn{2}{|c|}{11} & \multicolumn{2}{|c|}{11} \\
\hline $\mathrm{AR}(2)$ & \multicolumn{2}{|c|}{0.60} & \multicolumn{2}{|c|}{1.16} & \multicolumn{2}{|c|}{-0.50} \\
\hline$p$-value & \multicolumn{2}{|c|}{0.550} & \multicolumn{2}{|c|}{0.244} & \multicolumn{2}{|c|}{0.621} \\
\hline$J$ - statistic & \multicolumn{2}{|c|}{14.15} & \multicolumn{2}{|c|}{15.69} & \multicolumn{2}{|c|}{15.04} \\
\hline$p$-value & \multicolumn{2}{|c|}{1.000} & \multicolumn{2}{|c|}{1.000} & \multicolumn{2}{|c|}{1.000} \\
\hline
\end{tabular}

Notes: The J-statistics is a test of the over identifying restrictions and distributed as chi-squared under the null of instrument validity and AR (2) Arellano-Bond is the test of second-order autocorrelation in the first-differenced residuals.

*** $\mathrm{p}<0.01,{ }^{* *} \mathrm{p}<0.05,{ }^{*} \mathrm{p}<0.1$

In Model 1a of Table 2, the results suggest that banks' credit supply is related to one-period lagged credit supply positively and significantly. Such a result implies that the relevant banks hold more credit supply (debt ratio) previously continued to supply more credit. Inspecting the coefficients of banks' size, we find that banks' credit supply increases significantly with an increase in size. This result is also consistent with previous empirical studies that have reported the positive relationship between bank size and the credit supply of banks (Alper, Hulagu, and Keles (2012); Köhler, Hommel, and Grote (2006); Jimborean (2009). However, one should note that this result is contrary to Pruteanu (2004) and Janjua, Rashid, and Qurrat-Ul-Ain (2014), who found the negative association between bank size and credit supply. The coefficient of banks' liquidity is negative and statistically 
insignificant, suggesting that liquidity affects negatively the credit supply of banks. Similarly, Alper, Hulagu and Keles (2012) and Köhler, Hommel, and Grote (2006) found the negative effect of liquidity on banks' loan supply, but significant. It means that there is shortage of liquidity stock to absorb monetary policy shocks. Nevertheless, Jimborean (2009) and Hasin and Majid (2012) indicated a positive and significant relationship of banks' liquidity and loan growth, implying that liquid banks adjust the tightening of monetary policy.

Banks' capital appears with the co-efficient value of 0.005 indicating it is positively and significantly related to the credit supply of banks. Several studies in the literature such as Girardin and Moussa (2011), Jimborean (2009), Bernanke and Lown (1991) reported the positive relation of capital with the credit supply of banks. Further, the positive impact of capital supports the prediction of monetarists that well-capitalized banks survive more in contractions of monetary policy. The coefficient of coverage ratio is positive and statistically significant, suggesting that banks with high coverage ratio in their cash flow streams increase their supply of credit. Likewise, Kaleem and Isa (2006), Sanrego and Nikmawati (2010) and Alaro and Hakeem (2011) documented the positive relationship between coverage ratio and banks' credit supply. Credit risk appears to be negatively related to banks' credit supply, suggesting that when the credit risk of a bank increases the bank become conscious in issuing loans. Such a finding is consistent with the findings of Pruteanu (2004), which highlights that the classified loans become a basic source to increase credit risk because it is defined as ratio of classified loans to total loans. Banks' profitability is positively and significantly associated to banks' credit supply decision. The debt to equity ratio appears to affect credit supply positively and significantly, indicating that as the debt to equity ratio grows, the banks supply more credit to market because the banks are capable to issue more credit.

The GDP growth is found positive and significant in all three regressions, suggesting that an increase in GDP growth will lead to an increase of credit growth in banks. Because, there is substantial reward to supply the funds in a growing economy. Inflation is also found positively and significantly related to credit growth of banks in line with the existing literature.

In Model 1b of Table 2 and Model 1c of Table 2, we regress banks credit supply on bank specific characteristics with the interest rate spread and the deposit rate, respectively, as monetary policy indicator and with macroeconomic indicators. All the bank specific and macroeconomic variables are consistent with the results of previous Model 1a of Table 2. The interest rate-spread and the deposit rate negatively and significantly related to the banks' credit supply testifying the bankcentric view of monetary policy.

In Panel B of Table 2, the diagnostic tests reveal that our instruments are robust. Especially, the estimates of J-test do not provide any significant evidence in favor of rejecting the null hypothesis. Similarly, we do not find any significant evidence of the existence of autocorrelation in the residuals. Overall, these diagnostic tests prove the validity of the instruments. 


\subsection{Findings for Malaysia}

The empirical results for Malaysia are presented in Table 3. Panel A and Panel $B$ present the empirical results of variables and diagnostic tests, respectively. In Panel A of Table 2, the monetary policy indicators; the lending interest, the interest rate-spread, and the deposit rate indicate the negative and statistically significant coefficients, confirming the presence of the bank-centric view of monetary policy.

Table 3.

Impact of Monetary Policy Indicators on Islamic banks' Credit Supply in Malaysia

\begin{tabular}{|c|c|c|c|c|c|c|}
\hline \multicolumn{7}{|c|}{ Panel A: Estimation Results } \\
\hline & \multicolumn{2}{|c|}{ Model 2 (a) } & \multicolumn{2}{|c|}{ Model $2(b)$} & \multicolumn{2}{|c|}{ Model 2(c) } \\
\hline Variables & Coefficient & SE & Coefficient & SE & Coefficient & SE \\
\hline Debt Ratio (t-1) & $0.685^{* * *}$ & 0.114 & $0 . .861^{* * *}$ & 0.093 & $0.693^{* * *}$ & 0.077 \\
\hline Banks size & $0.007^{* *}$ & 0.015 & $0.009^{* *}$ & 0.050 & $0.003^{* *}$ & 0.006 \\
\hline Banks Liquidity & $-0.496^{* * *}$ & 0.138 & $-0.331^{* * *}$ & 0.064 & $-0.307^{* * *}$ & 0.085 \\
\hline Banks Capital & $0.469^{* *}$ & 0.014 & $0.288^{* * *}$ & 0.098 & $0.005^{* * *}$ & 0.001 \\
\hline Coverage ratio & 0.044 & 0.567 & 0.440 & 0.784 & 0.477 & 0.563 \\
\hline Credit risk & $-0.110^{* * *}$ & 0.043 & $-0.030^{* * *}$ & 0.007 & $-0.022^{* * *}$ & 0.003 \\
\hline Banks Profitability & $0.021^{* * *}$ & 0.007 & $0.011^{* * *}$ & 0.003 & $0.024^{* * *}$ & 0.007 \\
\hline Debt to equity ratio & $-0.002^{* * *}$ & 0.001 & $-0.001^{* * *}$ & 0.001 & $-0.003^{* * *}$ & 0.002 \\
\hline Lending rate & $-0.043^{* * *}$ & 0.012 & & & & \\
\hline Interest rate spread & & & $-0.042^{* * *}$ & 0.002 & & \\
\hline Deposit rate & & & & & $-0.043^{* * *}$ & 0.003 \\
\hline GDP Growth & $0.278^{* *}$ & 0.156 & $0.009^{* *}$ & 0.020 & $0.089 *$ & 0.093 \\
\hline Inflation & $0.004^{*}$ & 0.016 & $0.004^{* *}$ & 0.015 & $0.014^{* *}$ & 0.006 \\
\hline Constants & -0.566 & 0.648 & $0.285^{* *}$ & 0.039 & $-0.088^{*}$ & 0.080 \\
\hline \multicolumn{7}{|c|}{ Panel B: Diagnostic Tests } \\
\hline Observations & \multicolumn{2}{|c|}{107} & \multicolumn{2}{|c|}{107} & \multicolumn{2}{|c|}{107} \\
\hline Banks & \multicolumn{2}{|c|}{11} & \multicolumn{2}{|l|}{11} & \multicolumn{2}{|c|}{11} \\
\hline $\mathrm{AR}(2)$ & \multicolumn{2}{|c|}{0.41} & \multicolumn{2}{|c|}{0.40} & \multicolumn{2}{|c|}{0.84} \\
\hline$p$-value & \multicolumn{2}{|c|}{0.684} & \multicolumn{2}{|c|}{0.690} & \multicolumn{2}{|c|}{0.401} \\
\hline$J$ - statistic & \multicolumn{2}{|c|}{15.05} & \multicolumn{2}{|c|}{13.20} & \multicolumn{2}{|c|}{15.24} \\
\hline$p$-value & \multicolumn{2}{|c|}{1.000} & \multicolumn{2}{|c|}{1.000} & \multicolumn{2}{|c|}{1.000} \\
\hline
\end{tabular}

We regress the credit supply of Islamic banks on the lending interest, the interest rate spread and the deposit rate separately in different three regressions for Malaysia. The empirical results are consistent with the bank-centric view of monetary policy (Kashyab and Stein, 1994). Similarly, these results are in accordance with the existing literature including Sharpe (1995), Hasin and Majid (2012) and Janjua, Rashid and Qurrat-Ul-Ain (2014).

In Table 3, these results are similar to the results presented in Table 2 for all three regressions. Further, the coefficient value of the credit supply suggests that Islamic banks' credit supply is positively and significantly related to one-period lagged credit supply in Table 3. This implies that those banks hold more credit 
supply previously would supply more credit in the following period as well. Bank size, banks' capital, the coverage ratio, and the profitability of banks are positively and significantly related to the credit growth of banks in Malaysia. The coefficients of banks' liquidity, the credit risk and debt to equity ratio are negatively and significantly related to banks' credit supply. Only the debt to equity ratio changes its sign from positive to negative when it is regressed with the monetary policy measure of BNM.

In Table 3, GDP growth is found positive and significant in all three regressions, suggesting that an increase in GDP growth will lead to an increase of credit growth in banks. This is because, there is a substantial reward to supply the funds in a growing economy. Inflation is also found positively and significantly related to the credit growth of banks and this finding is consistent with the existing literature.

In Panel B of Table 2, the diagnostic tests reveal that our instruments are robust. Especially, the estimates of J-test do not provide any significant evidence in favor of rejecting the null hypothesis. Similarly, we do not find any significant evidence of the existence of autocorrelation in the residuals. Overall, these diagnostic tests prove the validity of the instruments.

\subsection{Differential Impact of Monetary Policy Measures on Credit Supply of Islamic Banks in Pakistan versus Malaysia}

In Table 4, we can observe the coefficient values of alternative monetary policy measures comparatively between Pakistan and Malaysia. The values of monetary policy measures are taken for Pakistan from Table 2 and for Malaysia from Table 3. We have shown the differential impact of three monetary policy measures in both models and found that credit supply channel is more effective in Malaysia as compared to Pakistan.

Table 4.

Differential Impact of Monetary Policy Measures on Credit Supply of Islamic Banks in Pakistan versus Malaysia

\begin{tabular}{llcc}
\hline & $\begin{array}{l}\text { Lending Interest } \\
\text { Rate }\end{array}$ & $\begin{array}{c}\text { Intertest Rate } \\
\text { Spread }\end{array}$ & $\begin{array}{c}\text { Deposit Interest } \\
\text { Rate }\end{array}$ \\
\hline Model 1 (Pakistan) & $-0.022^{* * *}$ & $-0.024^{* * *}$ & $-0.021^{* * *}$ \\
Model 2 (Malaysia) & $-0.043^{* * *}$ & $-0.042^{* * *}$ & $-0.043^{* * *}$ \\
\hline
\end{tabular}

Malaysian Islamic banking sector is found efficient and smoothly working. In Malaysia, the banking sector documents $4.7 \%$ of GDP, boasting assets worth $198.8 \%$ of GDP and hold 3\% of the total employed force of the country in 2016. Comparatively effective monetary policy of Malaysia is evident of professional commitment of the central bank of Malaysia. BNM's monetary policy actions are conducted to stable the prices through keeping an eye on economic growth of country. In addition, BNM plays a vital role in development of a progressive, sound and diversified financial sector that leads to the financial system stability. It also takes initiatives to deepen the financial markets role in development of real 
economy, including the foreign exchange market. Similarly, BNM also supervises the framework of nation's payment systems that ensures the efficiency of financial markets and security of the financial systems. Moreover, it has played an important role in developing the infrastructure for financial inclusion through easing the public to access to financial services. BNM advises the government, as a banker and an adviser, on the macroeconomic public policies and the management of public debt. It is also an independent authority with a sole right to issue the national currency and to manage the international reserves of Malaysia. These functions of BNM may develop a conducive environment to work credit supply channel of banks efficiently as compared to Pakistan.

In Malaysia, Islamic banking sector is also found more effective as compared to that of Pakistan because of well-developed infrastructure. The Islamic banks are not entirely based on the interest rate rather the IBOR is existing (Islamic Banking Offered Rate) determined in Islamic Inter-bank Money Market (IIMM) in Malaysia. "A variety of monetary instruments can be development and devised on the basis of different Islamic contracts. These instruments of IIMM include Government Investment Issue (GII), Mudarabah Interbank Investment (MII), Wadiah Acceptance (WA), Islamic Accepted Bills (IAB), Islamic Negotiable Instruments (INI), Bank Negara Monetary Notes-i (BNMN-i), Sell and Buy Back Agreement (SBBA), Cagamas Mudharabah Bonds (SMC), Sukuk BNM Ijarah (SBNMI), When Issue (WI), Islamic Private Debt Securities, and Ar Rahnu Agreement-I (RA-i)."

Overall, Pakistan needs to learn from the successful experience of Malaysia, especially in developing Islamic financial market and improving institutions quality that will make it able to transmit the monetary policy through credit supply channel efficiently.

\section{CONCLUSION AND POLICY IMPLICATIONS}

The credit supply channel of monetary policy has recently received an increased attention after the financial crisis of 2007-09. In this paper, we have examined the existing of credit-view channel of monetary policy and the impact of monetary policy on credit supply of Islamic banks between Pakistan and Malaysia. In empirical models, three alternative measures of monetary policy are regressed on banks' credit supply, several bank-specific variables and macroeconomic indicators are considered as control variables. Estimating the models for both countries separately, we provide the strong evidence on the existence of credit supply cannel of monetary policy through Islamic banks. The results indicate that Islamic banks respond more to monetary policy measures in Malaysia as compared to that of Pakistan. The relatively less response of Islamic banks to monetary policy in Pakistan may make it difficult for SBP to achieve the desired objectives of the monetary policy.

There are several policy implications for monetary policy authorities of economies with dual banking system like Pakistan, Malaysia, Indonesia, Bahrain, Saudi Arabia, Qatar and others. First, the central bank should manage interest rate to stabilize the credit supply through Islamic banks because the bank-centric view of monetary policy is active in these economies. Second, our findings suggest that for an effective monetary policy, there is a vital need to consider the unique nature 
of Islamic banks while devising the instruments to manage credit supply in the economy, otherwise there may appear puzzles to monetary policy actions. This study suggests policymakers to consider Islamic financing as complement channel to the monetary policy transmission mechanism.

At the end, we are of the view that researchers, academicians and policymakers can take benefits while devising Islamic financial products and monetary instruments from a successful experience of Malaysia especially. Although, a sound Shari'ah appraisal would be required as a future research agenda, of these Islamic monetary instruments that are based upon controversial vehicle contracts like BaiInna, commodity Murabh'ah etc. among jurists of different territories. This area of research is a challenge for future researchers to find out the ways to harmonize these juristic opinions in domain of Islamic monetary instruments, enabling the industry to move to the development of global Islamic financial market.

\section{REFERENCES}

Akhatova, M., Zainal, M.P., \& Ibrahim, M.H. (2016). Banking Models and Monetary Transmission Mechanisms in Malaysia: Are Islamic Banks Different? Economic Papers, 35(2), 169-183.

Alaro, A. R., \& Hakeem, M. (2011). Financial Engineering and Financial Stability: The Role of Islamic Financial System. Journal of Islamic Economics, Banking and Finance, 7(1), 34-55.

Alper, K., Hulagu, T., \& Keles, G. (2012). An Empirical Study on Liquidity and Bank Lending. Central Bank of the Republic of Turkey, Working Paper, 4.

Anwar, S., \& Nguyend, L. P. (2018). Channels of Monetary Policy Transmission in Vietnam. Journal of Policy Modelling, 40(4), 709-729.

Arellano M., \& Bond S. (1991). Some Tests of Specification for Panel Data: Monte Carlo Evidence and An Application to Employment Equations. Review of Economic Studies, 58(3), 277-297.

Arellano M., \& Bover O. (1995). Another Look at the Instrumental Variable Estimation of Error-Components Models. Journal of Econometrics 68, 29-51.

Auclert, Adrien (2017). Monetary Policy and The Redistribution Channel. NBER Working Paper Series, Working Paper 23451, Cambridge, MA 02138.

Aysun, U. \& Hepp, R. (2013). Identifying the Balance Sheet and the Lending Channels of Monetary Transmission: A Loan-Level Analysis. Journal of Banking $\mathcal{E}$ Finance, 37(2), 2812-2822.

Bernanke, B. S., Lown, C. S., \& Friedman, B. M. (1991). The Credit Crunch. Brookings Papers on Economic Activity. 22(2), 205-248.

Bernanke, B.S. \& Blinder A.S. (1995). Inside the Black Box: The Credit Channel of Monetary Policy Transmission. Journal of Economic Perspectives, American Economic Association, Fall 9(4), 27-48.

Bernanke, B.S., Gertler, M. \& Gilchrist, S. (1999). The Financial Accelerator in a Quantitative Business Cycle Framework. Handbook of Macroeconomics. Amsterdam: Elsevier.

Blundell R., \& Bond, S. (1998). Initial Conditions and Moment Restrictions in Dynamic Panel Data Models. Journal of Econometrics 87(2), 115-143. 
Cecchetti, S., G. (1999). Legal Structure, Financial Structure, and the Monetary Policy Transmission Mechanism. NBER Working Paper No. W 7151.

Chapra, M. U. (1985). Towards A Just Monetary System. Leicester: The Islamic Foundation, 223 London Road, Leicester, UK.

Chaudary N, N., \& Mirakhor, Abbas. (1997). Indirect Instruments of Monetary Controlling an Islamic Financial System. Islamic Economic Studies, 4(2), 27-65.

Ehrmann, M., Gambacorta, L., Martínez-Pagés, J., Sevestre, P., \& Worms, A., (2001). Financial Systems and the Role of Banks in Monetary Policy Transmission in the Euro Area. ECB Working Paper, 105.

Erdogdu, Aylin, (2017). Functioning and Effectiveness of Monetary Transmission Mechanisms: Turkey Applications. Journal of Finance and Bank Management, American Research Institute for Policy Development, 5(1), 29-41.

Evans, C., Fisher, J., Gourio, F., \& Kran, S. (2015). Risk Management for Monetary Policy Near the Zero Lower Bound. Brookings Papers on Economic Activity, 141219.

Farahani, Y, G., \& Dastan, M. (2013). Analysis of Islamic Banks' Financing and Economic Growth: A panel co-integration approach. International Journal of Islamic and Middle Eastern Finance and Management, 6(2), 156-172.

Friedman, M., and Schwartz, A. J. (1963). A Monetary History of the United States, 1867-1960. Princeton: Princeton University Press, New Jersey, USA.

Gertler, M., \& Gilchrist, S. (1993). The Role of Credit Market Imperfections in the Monetary Transmission Mechanism: Arguments and Evidence. The Scandinavian Journal of Economics, 95(1), 43-64.

Girardin, E., \& Moussa, Z. (2011). Quantitative Easing Works: Lessons from the Unique Experience in Japan 2001-2006. Journal of International Financial Markets, Institutions and Money, 21(2), 461-495.

Hardianto, Erwin. (2004). Shariah Transmission Mechanism in Indonesia. Journal of Economic Cooperation and Development, 8(2), 20-38.

Janjua, P. Z., Rashid, A., \& Qurrat-Ul-Ain. (2014). Impact of Monetary Policy on Bank' Balance Sheet in Pakistan. International Journal of Economics and Finance, 6(11), 187-196.

Jermann, Urban (2019). Negative Swap Spreads and Limited Arbitrage. NBER Working Paper No. 25422.

Jimborean, R. (2009). The Role of Banks in the Monetary Policy Transmission in the New EU Member States. Economic Systems, 33 (2), 360-375.

Kaleem, A., \& Isa, M. (2006). Islamic Banking and Money Demand Function in Malaysia: An Econometric Analysis. Pakistan Economic and Social Review, XLIV (2), 277-290.

Kashyab, A. K., \& Stein, J. C. (1994). Monetary Policy and Bank Lending in Monetary Policy. Chicago: The University of Chicago Press, USA.

Kashyab, A. K., \& Stein, J. C. (1995). The Impact of Monetary Policy on Bank Balance Sheets. NBER, Working Paper No. 4821.

King, Robert G. and Charles I. Plosser (1984). Money, Credit, and Prices in a Real Business Cycle. The American Economic Review, 74(3), 363-380.

Kishan, R. P., \& T. P. Opiela. (2000). Bank Size, Bank Capital, and the Bank Lending Channel. Journal of Money, Credit and Banking, 32(1), 121-141. 
Köhler, M., Judith H., \& Matthias, G. (2006). The Role of Banks in the Transmission of Monetary Policy in the Baltics. Centre for European Economic Research (ZEW), Discussion Paper, 06-005.

Majid, M. S., \& Hasin, Z. (2012). Islamic Banks and Monetary Transmission Mechanism in Malaysia. Journal of Economic Cooperation and Development, 35(2), 137-166.

Mishkin, F. S. (1996). The Channels of Monetary Transmission: Lesson for Monetary Policy. NBER Working Paper No. 5464.

Pruteanu, Anca. (2004). The Role of Banks in the Czech Monetary Policy Transmission Mechanism. Czech National Bank, Working Papers 2004/03.

Sanrego, Y. D., \& Nikmawati, K. (2010). Transmission Mechanism of Sharia Financing in Malaysia. The Journal of Muamalat $\mathcal{E}$ Islamic Finance, Research (JMIFR). 7(1). 121-135.

Sanrego, Y. D., \& Rusydiana A. S. (2013), Transmission Mechanism in Dual Monetary System: Comparison between Shariah and Conventional Monetary System. Journal of Islamic Economics, Banking and Finance, 9(2). 111-124.

Santis, R. A., \& Surico, P. (2013). Bank Lending and Monetary Transmission in the Euro Area. Economic policy, 28(75), 423-457.

Shah, M. A. Rehman., Rashid, A., \& Zaman, M. Khaleequz. (2017). Capital Structure Decisions in Islamic Banking: Empirical Evidence from Pakistan. Journal of Islamic Banking and Finance, 34(2), 88-103.

Shah, M. A. Rehman., Rashid, A. and Mansoori, M. Tahir. (2018). The Role of Islamic versus Conventional Banks in Monetary Policy Transmission: An Empirical Investigation for Pakistan. FWU Journal of Social Sciences. Summer 2018, 12(1), 56-72.

Sharpe, Steven A. (1995). Bank Capitalization, Regulation, and the Credit Crunch: A Critical Review of the Research Findings. Board of Governors of the Federal Reserve System, Finance and Economics Discussion Series No. 12(1). 95-20.

Sims, C., (1992). Interpreting the Macroeconomic Time Series Facts: The Effects of Monetary Policy. European Economic Review, 36(5), 975-1000.

Stepanchuk, S., Tsyrennikov, V. (2015). Portfolio and Welfare Consequences of Debt Market Dominance. Journal of Monetary Economics, 74 (2), 89-101.

Sukmana, R., \& Kassim, S. H. (2010). Roles of the Islamic Banks in the Monetary Transmission in Malaysia. International Journal of Islamic and Middle Eastern Finance and Management, 3(1), 7-19.

Wong, K. (2000). Variability in the Effects of Monetary Policy on Economic Activity. Journal of Money, Credit and Banking, 32(2), 179-198.

Zaheer, Sajjad., Ongena, S., \& Wijnbergen S. J. G. (2013). The Transmission of Monetary Policy Through Conventional and Islamic Banks. International Journal of Central Banking Duha 8(2), 175-224. 
This page is intentionally left blank 